\title{
Marshmallow Flavor
}

National Cancer Institute

\section{Source}

National Cancer Institute. Marshmallow Flavor. NCI Thesaurus. Code C82400.

A characteristic of a medicinal product, specifying that its most predominant agreeable savor detected by the unified sensation of taste and olfactory receptors resembles marshmallow. 